\title{
Power of Sale Foreclosure after Fuentes
}

Two types of foreclosure proceedings are generally used in the United States: foreclosure by judicial action and foreclosure by private sale. ${ }^{1}$ The former requires the creditor to sue in equity to gain judicial permission and supervision for sale of the real estate and distribution of the proceeds; the latter permits the creditor, without resorting to the courts, to sell the property either at an auction or through private negotiation. ${ }^{2}$

According to a recent report of the American Bar Association Committee on Real Estate Financing, ${ }^{3}$ judicial sales, on the average, cost more and take longer than private sales. ${ }^{4}$ The ten states with the least expensive foreclosure procedures use private sale; eight of the ten states with the most expensive foreclosure procedures use judicial sale. ${ }^{5}$ Although it is difficult to isolate private sale from other factors, such as delays due to statutory redemption periods and congested court

1 This comment is concerned with mortgage foreclosure procedures and makes no attempt to discuss procedures for eviction of a tenant under an installment land contract. The installment land contract places the buyer in the position of a tenant except that, after the "pay-out" period, the seller conveys his interest in the land to the buyer. The buyer receives no deed until he pays the seller the entire purchase price, and the seller has all of the remedies of a landlord. This method of financing has become a popular method to finance housing for low-income families because of lower move-in costs and lower down-payment requirements for the buyer, and because the seller can obtain an adequate return on his capital given the expeditious remedies for default. The widespread use of installment land contract financing in judicial foreclosure states is an indication of lenders' and borrowers' dissatisfaction with the costs of judicial foreclosures. Mixon, Installment Land Contracts: A Study of Low Income Transactions, With Proposals for Reform and a New Program to Provide Home Ownership in the Inner City, 7 Houston L. REv. 523 (1970). See also Hines, Forfeiture of Installment Land Contracts, 12 U. KAN. L. REv. 475 (1964).

2 G. OSBorne, HandBook on THE LAW OF Mortgages $\S \S 318,337$ (2d ed. 1970). The exercise of the power of sale may be performed either by the creditor himself, or by a third party in the case of a trust deed where the trustee is responsible for the sale.

3 ABA Committee on Real Estate Financing, Cost and Time Factors in Foreclosure of Mortgages, 3 Real Property, Probate \& Trust J. 413 (1968). [hereinafter cited as ABA Committee].

4 Id. at 414; see text and note at note 31 infra.

5 The ten states with the least expensive foreclosure methods are (from low to high cost) Texas, Maine, Nevada, Alabama, New Hampshire, Virginia, Tennessee, Mississippi, Idaho, and Michigan. The cost of foreclosure in the District of Columbia, which also uses power of sale, is roughly equivalent to the cost in Alabama. The ten states that have the most costly procedures are (from low to high cost) New York, Montana, Kentucky, South Carolina, West Virginia, Wisconsin, Delaware, Illinois, Maryland, and Utah. Only Maryland and West Virginia use power of sale. Id. at 414. 
dockets, the ABA study and other commentators have concluded that private sale significantly lowers the costs of foreclosing mortgaged property. ${ }^{6}$

Several states have recently enacted legislation permitting foreclosure by private sale, ${ }^{7}$ and the proposed Uniform Land Transactions Code recommends that it be adopted as the main method of foreclosure. ${ }^{8}$ This comment reviews the history of foreclosure by private sale, considers its desirability, and attempts to determine whether its use can be reconciled with constitutional standards of procedural due process.

\section{Comparison of Judicial foreclosure and Power of Sale}

\section{A. Foreclosure by Judicial Sale}

In early English mortgage law, a mortgage was a conveyance of an estate in land, either in fee simple or for a long term of years, with the condition subsequent that the conveyance would be void and the grantor/mortgagor would have a right of entry if he paid a stated sum of money or performed some other obligation on a specified date. No indication of the purpose of the transfer appeared in the formal conveyance document, and the mortgagee had all of the incidents of legal title including dower and possession. ${ }^{9}$ If, for whatever reason, the mortgagor failed to pay on time, his right of reentry was lost at law and the mortgagee became the absolute owner of the property. To prevent unfair behavior, however, equity courts compelled unjust mortgagees to reconvey land if the mortgagor subsequently paid the debt plus interest from the original due date. As a result, to perfect his title a mortgagee had to ask the equity court to fix a time for the mortgagor either to pay the debt or to forfeit his right of redemption. ${ }^{10}$ In order to allow the mortgagor to recoup his investment without forcing him to redeem in full, equity courts eventually required foreclosure by

- Commentators generally seem to accept the notion that judicial foreclosure is more costly than a power of sale. See, e.g., ABA Committee, supra note 3; Carey, Brabner-Smith, \& Sullivan, Studies in Foreclosures in Cook County: II. Foreclosure Methods and Redemption, 27 ILL. L. REv. 595 (1933); Fairchild, Foreclosure Methods \& Costs: A Revaluation, 7 BroorLyn L. Rev. 1 (1937); Prather, A Realistic Approach to Foreclosure, 14 Bus. LAw. 132 (1958); Prather, Foreclosure of the Security Interest, 1957 U. ILL. L.F. 420; Reeve, The New Proposal for a Uniform Real Estate Mortgage Act, 5 LAw \& ConteMP. Prob. 564 (1938); Note, Power of Sale: An Alternative to Judicial Foreclosure, 21 U. FLA. L. REv, 392 (1969).

7 See text and notes at note 22 infra.

8 Uniform Land Transactions Code, \& 3-508 (Tent. Draft No. 2, Aug., 1972) [hereinafter cited as ULTC].

9 For a short history of the development of the mortgage, see A. DunhaM, Modern Rear Estate Transactions 281-3 (2d ed. 1958).

$10 \mathrm{Id}$. at 282. 
sale. ${ }^{11}$ This common law development of foreclosure by judicial sale was an attempt by the courts to reconcile two seemingly competing interests: the interest of the lender in having a reasonably efficient method of realization on mortgaged property after a default by the borrower, and the interest of the borrower in having an opportunity to remedy a default when the creditor has not behaved reasonably or when other circumstances justify a right of redemption. ${ }^{12}$

Foreclosure by judicial sale is generally slow and expensive. After any grace periods have expired, the mortgagee must conduct a title search to be certain that all necessary parties are joined in the complaint. The complaint must then be prepared and filed, along with a notice of lis pendens, and a summons served. The defendant is then allowed time to prepare and file his answer and to appear in court.13 Once the court orders foreclosure, notice of the sale is required. After sale (generally to the mortgagee), court confirmation is necessary. Statutory redemption may then be available for as long as two years..$^{14}$

\section{B. Foreclosure by Private Sale}

Power of sale is a contractual right, either provided in a mortgage or incorporated by statute, that entitles a creditor to sell mortgaged property after a debtor's default without resorting to judicial proceedings. ${ }^{15}$ Although power of sale antedates the Constitution and has been

$11 I d$. In Connecticut the historic method of foreclosure is strict foreclosure, although courts may order foreclosure by sale on their own initiative or the request of the parties. ABA Committee, supra note 3, at 418.

12 Currently, the English Law of Property Act balances these factors in a manner that allows the power of sale-giving a mortgagee of land the right to sell on any terms and conditions and at either "public auction or by private contract." 15 \& 16 Geo. 5, c. 20, § 101 (1925).

13 A mortgagor who wants to delay the foreclosure is usually able to gain at least one postponement of the hearing.

14 See generally Fairchild, supra note 6, at 2-3; Prather, Foreclosure of the Security Interest, 1957 U. IxL. L.F. 420, 432. Although the sale is public, 99.3 percent of the properties are purchased by the mortgagee, which raises some doubts about the value of a public sale. Prather, A Realistic Approach to Foreclosure, 14 Bus. LAw. 132, 135 (1958).

15 See, e.g., Sale City Peanut \& Milling Co. v. Planters \& Citizens Bank, 107 Ga. App. 463, 130 S.E.2d 518 (1963); Faine v. Wilson, 192 S.T.2d 456 (Tex. Civ. App. 1946). A power of sale may aIso be created by a separate instrument, if it is not inconsistent with the mortgage provisions. Cartledge v. Trust Co., 186 Ga. 718, 198 S.E. 741 (1938); Watson v. Sherman, 84 Ill. 263 (1876); Peaslee v. Ridgway, 82 Minn. 288, 84 N.W. 1024 (1901). Power of sale is similar to self-help provisions that have been recognized and accepted throughout the history of the law. This relationship has been noted, for example, in Ricks v. Goodrich, 3 La. Ann. 212 (1848) (finding predecessor of power of sale in Roman pledge of personal property). During the classical period of Athenian history (500 to 400 B.C.) the contractual right to repossess personal property was already recognized. If the property remained in the possession of the debtor, the creditor was entitled to take possession of the property, by force if necessary. A. Harrison, The LAw of Athens 258 (1968). Similar rights of self-help repossession existed in the Roman fiducia cum creditore, which allowed 
considered a part of our common law, ${ }^{16}$ many courts in this country scrutinize sales under such powers very carefully. ${ }^{17}$ In some states, the courts uniformly set aside the title of a mortgagee who buys at his own sale because of the potential for abuse. ${ }^{18}$ In other cases, if the mortgagor challenges the legality of a mortgagee's attempted use of the power of sale either because the power is used as a vehicle for "abuse and oppression," because there has been, in fact, no default, or because the mortgagee has otherwise failed to comply with statutory requirements, the debtor may be able to obtain a preliminary injunction against the sale and, if successful, a permanent injunction. ${ }^{19}$ In addition, if the sale is conducted improperly, the mortgagor may recover the value of his equity in the property. ${ }^{20}$ In a few states close judicial scrutiny of such sales often makes power of sale more costly for mortgagees than judicial foreclosure. ${ }^{21}$ In a majority of states, however, mortgagees use power of sale because it is less expensive than judicial foreclosure. ${ }^{22}$

Power of sale is regulated in most states by statutes similar to the

the debtor to retain possession prior to default. W. BuckIAND, A MaNual of Roman Private Law 352 (1939); W. Buckrand, A TextBook of Roman LaW from Augustus to JUSTINIAN 475 (2d ed. 1932); W. BUGRLAND, \& A. MCNAIR, RoMan LAw AND ComMON LAW 314 (1965). Since French civil law was in large part derived from the Roman legal system, it also recognized the right of parties to a contract to agree upon provisions allowing the creditor to seize the property in the event of a default. 1 DoMAT, THE Crvil LAW IN ITS Natural ORder 676 (Strahan Transl. 1850).

16 See Carey, Brabner-Smith, \& Sullivan, supra note 6, at 616; Comment, Non-Judicial Repossession-Reprisal in Need of Reform, B.C. IND. \& CoM. L. Rev. 435 (1970). See generally Ricks v. Goodrich, 3 La. Ann. 212 (1848).

17 See, e.g., Sanderlin v. Cross, 172 N.C. 234,90 S.E. 213 (1916); Tedlock v. Torbert, 89 Okl. 218, 215 P. 196 (1923); Johnson v. Johnson, 27 S.C. 309, 3 S.E. 606 (1887); Reisenberg v. Hankins, 258 S.W. 904 (Tex. Civ. App. 1924).

18 See, e.g., Shew v. Call, 119 N.G. 450, 26 S.E. 33 (1896). Because of the careful judicial scrutiny, the purchaser at the sale may be forced to defend the validity of his title under the sale; a purchaser at a judicial foreclosure sale generally receives a much more secure title. G. OsBORNE, supra note 2, at 340.

19 ULTC § 3-514(1); Young v. Ridley, 309 F. Supp. 1308, 1312 (1970).

20 See Rogers v. Barnes, 169 Mass. 179, 47 N.E. 602 (1897).

21 Prompted by cases of "abuse and oppression" in the use of the power of sale, some state legislatures abolished it. Ventres v. Cobb, $105 \mathrm{Ill}$. 39 (1882). At one time or another the following states have abolished the power of sale: Arizona, Colorado, Idaho, Illinois, Indiana, Iowa, Kansas, Kentucky, Oklahoma, and Oregon. See 41 C.J. Mortgages § 1343, n.13 (1926).

22 There has been a steady increase in the use of power of sale over the past thirty-five years. In 1938, power of sale foreclosure was customarily used in only eighteen states, Reeve, supra note 6, at 565; by 1957 in twenty-one states, Prather, Foreclosure of the Security Interest, 1957 U. ILL. L.F. 420, 430; and by 1968 in twenty-seven states, ABA Committee, supra note 3, at 414 . Since 1963 Montana has reallowed power of sale for tracts of three acres or less. See MoNT. REv. CoDE ch. 93, § 6005 (1964), ch. 52, §§ 401-417 (Supp. 1971). 
proposed Uniform Land Transactions Code. ${ }^{23}$ Under the Code, after nonpayment there is a minimum grace period of five weeks before the mortgagee may officially notify the mortgagor of his intent to foreclose. ${ }^{24}$ After official notice has been given, there is an additional minimum grace period of three weeks after which the mortgagee must tell the mortgagor which default remedy he intends to use. ${ }^{25}$ If he elects power of sale, the mortgagee may hold the sale after "commercially reasonable advertisement" during the four weeks after the second notice is given..$^{26}$ Finally, there is a four week statutory redemption period after the sale. ${ }^{27}$ The mortgagee is required to behave in a "commercially reasonable" manner; if he behaves improperly, the mortgagor may sue for damages or for equitable relief. ${ }^{28}$

\section{Efficiency versus Procedural Protection}

In 1971, one hundred sixteen thousand mortgages were foreclosed in the United States and many more foreclosure proceedings were settled by deeds in lieu of foreclosure or in some other manner. ${ }^{29}$ By substituting power of sale for judicial sale as the general method of foreclosure states can eliminate the need for judicial intervention except in unusual cases, thus reducing the amount of litigation in this area, easing court congestion, and decreasing judicial expenses.

At the same time, it seems likely that use of the power of sale, rather than judicial sale, results in substantial savings to real estate creditors..$^{30}$

23 See generally Carey, Brabner-Smith, \& Sullivan, supra note 6, at 617 .

24 ULTC § 3-505. This same "grace period" is achieved in most states because mortgage forms generally define "default" as nonpayment for thirty days.

25 ULTC § 3-508. Other remedies that might be elected by a mortgagee after default include the appointment of a receiver, ULTC $\S 3-503$; acceptance of a deed in lieu of foreclosure, ULTC \& 3-507; and judicial foreclosure, ULTC § 3-509.

26 ULTC § 3-508.

27 ULTC \& $3-513$.

28 ULTC $\$ 3-514(2)$ provides that the minimum recovery is I percent of the initial unpaid obligation (with a maximum of $\$ 500$ ) and that any loss in excess of the minimum is also recoverable. In addition, ULTC \$ 3-514(3) provides for the recovery of attorney fees and other expenses of litigation.

295 FED. HOME LOAN BANK BD. J. 45 (June, 1972). No data is available concerning the number of deeds in lieu of foreclosure since they are informal settlements between mortgagee and mortgagor.

30 During the Depression the Home Owners' Loan Corporation studied the costs of foreclosure and found that the thirteen states with low-cost foreclosure methods were all nonjudicial foreclosure states. Of the thirty-five states classified in the middle or high cost groups, judicial foreclosure was the rule in all but six. Bridewell, The Effects of Defective Mortgage Laws on Fome Financing, 5 LAW \& ConTemP. Prob. 545, 558 (1938). It should be noted that the HOLG study and the ABA study included only "out-of-pocket" costs. If it had been possible to calculate the "opportunity costs," the costs for judicial foreclosure states would probably have been significantly higher. It is possible, however, to streamline the trial process, as has been done in Pennsylvania, through the use of con- 
There is some difficulty in estimating the extent to which private sale is less costly in both time and money than judicial sale since statutory redemption periods are provided in many states that use power of sale and account for a good share of the delay in the foreclosure process. It is possible, however, to take statutory redemption periods into account in order to get some idea of the relative efficiency of judicial and private sale, by comparing the costs of foreclosure in the nineteen private sale states that have no statutory redemption with the costs in the nine judicial sale states that also have no statutory redemption period. This comparison shows that thirteen of the private sale states complete the foreclosure process in an average time of two months or less, ${ }^{31}$ while all nine judicial sale states take more than two months. ${ }^{32}$

A comparison of the costs of foreclosure in all states, with and without statutory redemption periods, also indicates that, because it eliminates the need for a complaint, lis pendens notice, answer, and trial appearance, power of sale is substantially less expensive than judicial foreclosure. At present, the average time required to foreclose a mortgage completely in the judicial foreclosure states is eight months, at an average cost of about $\$ 775$; the average time for nonjudicial foreclosure is about four months with expenses averaging about $\$ 450 .^{33}$

It has been suggested that uniform use of the power of sale would encourage the development of a national mortgage market, increase the liquidity of mortgage debt, and increase the amount of funds available to the mortgage industry. ${ }^{34}$ The lower average cost of private foreclosure would probably have a significant effect on the mortgage

fession of judgment clauses in the mortgage instruments. ABA Committee, supra note 3, at 427. Such streamlining, however, essentially involves a decrease in judicial participation in the foreclosure process.

31 This does not include the normal one month "grace period" found in the Federal National Mortgage Association form and other mortgage forms.

32 See ABA Committee, supra note 3, at 414.

$33 \mathrm{Id}$. at 414 . Tennessee and Illinois illustrate the differences in time and money between foreclosure by power of sale and by judicial foreclosure. In Tennessee the average time is six or seven weeks and the average total cost is $\$ 265$. In Illinois, on the other hand, the average time is four months and the average cost $\$ 1,900$.

34 See Bridewell, supra note 30, at 549; D. Fand, Mortgage Market Impediments and Uniform State Land Transactions Laws, Aug., 1972, at 8-10 (unpublished paper presented at the conference, Housing the Poor: An Economic Analysis) (copy on file at The University of Chicago Law Review). In a recent survey, twenty of thirty-four national mortgage lenders cited lack of a uniform and inexpensive foreclosure law as either a "moderate" or "substantial" impediment to the development of a national mortgage market. ABA Committee on Real Estate Financing, Impediments to Free Flow of Funds in Mortgage Market, 6 Rear Property, Probate \& Trust J. 215 (1971). On the other hand, the study showed that such factors as statutory redemption periods, usury rates, and the costs of closing and real estate transfers, are also significant barriers to a national mortgage market. $I d$. 
market and, hence, on the construction industry and the economy as a whole. The higher costs of judicial sale that lenders expect to pay are currently reflected in the cost of mortgage money to debtors. Any decrease in costs to the lending industry should, therefore, result in a decrease in the price of mortgage money and an increase in the quantity of money available to borrowers. Thus, a decrease in foreclosure costs should have some or all of the following effects: decreased interest rates; increased loan-to-value ratios; more liberal extension of credit to marginal risk debtors; greater accomodation to the needs of the debtor in economic distress. ${ }^{35}$ The extent of this impact is not insignificant. While only 0.3 to 0.5 percent of the mortgage loans made in this country are foreclosed, and less than 1 percent of the properties foreclosed are ever redeemed, the amount of outstanding mortgage debt$\$ 500$ billion-makes the procedures used for securing payment important to the economy. ${ }^{36}$

The greater efficiency of power of sale foreclosure must, however, be purchased with at least some diminution of the procedural rights of the various parties. The mortgagee makes some sacrifices under the power of sale; he must accept responsibility for the sale and, in some states, he forfeits his rights to a deficiency judgment against the mortgagor. Since, however, the mortgagee is in a position to choose the method of foreclosure, the most important rights sacrificed are those of the mortgagor, who must give up some judicial protection and whose only recourse becomes an action of his own against the mortgagee-either to enjoin the sale or for damages after the completion of the sale.

The significance of this sacrifice is illuminated by the reasons for the development of judicial foreclosure. Private sale is open to many abuses: for example, the mortgagee may not make a good faith effort to realize any more than the amount of the debt, despite the fact that the mortgagor has considerable equity in the property; the mortgagee may foreclose through the power of sale for only a technical default, which a court might overlook; the mortgagee may foreclose because of factual errors, having failed to secure the proof of default that would be necessary in judicial foreclosure; the mortgagee may sell the property after a default that is the product of fraudulent or near-usurious terms in the mortgage contract, terms that a court would refuse to

35 Cf. Bridewell, supra note 30; D. Fand, supra note 34; Prather, Foreclosure of the Security Interest, 1957 U. IL. L.F. 420.

3658 FED. REs. BuLL. A55 (July, 1972). This compares with $\$ 137$ billion in consumer credit outstanding at the same time. 58 FED. REs. BuLL. A56 (July, 1972). 
enforce in judicial foreclosure. ${ }^{37}$ The efficiency and savings that are possible through the use of power of sale foreclosures are, therefore, at least partially offset by the potential for injustice that seems to be inherent in nonjudicial remedies.

In short, the chief consideration favoring private sale over judicial sale is greater efficiency in the use of both judicial resources and the resources available for real estate financing. If, however, the rights of mortgagors, which judicial foreclosure protects, are deemed to be substantial, they may not be abridged by the state in order to avoid litigation and judicial expense. ${ }^{38}$ And while the savings that power of sale foreclosure affords to real estate creditors may be returned to the general class of mortgagors, these savings can be obtained only by sacrificing rights that would protect some borrowers from unjust foreclosure. The matter can be viewed, therefore, as a question of justice: who should bear the risks of unjust foreclosure, all borrowers or only the individual whose mortgage is foreclosed? In recent years many state legislatures have implicitly decided this question by permitting foreclosure by private sale. Since, under modern conditions, most mortgage lenders are not in the business of managing real estate, and since foreclosure is generally a remedy of last resort, ${ }^{38}$ it appears that these legislative determinations have much validity. At the same time, however, there is some question whether power of sale comports with recent Supreme Court decisions finding similar creditor remedies unconstitutional.

\section{Due Process and Power of Sale}

Procedural due process generally requires that a person be afforded notice and an opportunity to be heard before the government can deprive him of life, liberty, or property. ${ }^{40}$ Until recently, the Supreme

37 See generally Contract Buyers League v. F \& F Investment, 300 F. Supp. 210 (N.D. IIl. 1969).

38 Cf. Miranda v. Arizona, 384 U.S. 436, 472-3 (1966); Gideon v. Wainwright, 372 U.S. 335, 341-2 (1963).

39 See D. Fand, supra note 34, at 11; FNMA Servicer's Guide, Instructions in Case of Default, §§ 127-128; Johnson, Denial of Self-Help Repossession: An Economic Analysis, appended to Brief for Permanent Editorial Board for the U.C.C. as amicus curiae, Adams v. Southern Cal. First Nat'l Bank, No. 72-1484 (9th Cir. 1972).

40 The Supreme Court relied on this principle at least as early as 1863 when it held in Baldwin v. Hale, 68 U.S. (1 Wall.) 223, that a discharge under a state insolvency law was ineffective against an out-of-state creditor. "Parties whose rights are to be affected are entitled to be heard; and in order that they may enjoy the right they must first be notified. Common justice requires that no man shall be condemned in his person or property without notice and an opportunity to make his defence." 68 U.S. (1 Wall.), at 
Court seldom applied the principles of due process to the remedies that the state makes available to private creditors. ${ }^{41}$ After the Court's decision in Sniadach v. Family Finance Corp., ${ }^{42}$ however, courts have invalidated various prejudgment security remedies on procedural due process grounds. ${ }^{43}$ Since power of sale is similar to the prejudgment security remedies that have been found unconstitutional, a review of Sniadach and its progeny is necessary.

\section{A. Sniadach and Fuentes}

In Sniadach, a finance company initiated garnishment proceedings against a debtor and her employer as garnishee, alleging a claim of $\$ 420$ on a promissory note. Pursuant to state law, $\$ 31.59$ of the debtor's weekly wages of $\$ 65$ were frozen when the creditor obtained a sum-

233. Since that time notice and an opportunity for a hearing have frequently been held to be fundamental requirements of procedural due process. Anderson Nat'l Bank v. Luckett, 321 U.S. 233 (1944) ("The fundamental requirement of due process is an opportunity to be heard upon such notice and proceedings as are adequate to safeguard the right for which the constitutional protection is invoked." Id. at 246); Best v. Humboldt Placer Mining Co., 371 U.S. 334 (1963) ("Due process . . . implies notice and a hearing." Id. at 338); Mullane v. Central Hanover Bank \& Trust Co., 339 U.S. 306 (1950) ("[T]he Due Process Clause ... at a minimum ... require[s] that deprivation of life, liberty or property by adjudication be preceded by notice and opportunity for hearing appropriate to the nature of the case." Id. at 313).

41 See, e.g., Ewing v. Mytinger \& Casselberry, Inc., 339 U.S. 594 (1950) (Department of Agriculture allowed to seize misbranded products under Food, Drug \& Cosmetic Act without a hearing); Fahey v. Mallonee, 332 U.S. 245 (1947) (Federal Home Loan Bank Board allowed to appoint conservator to take over management of a federal savings and loan without prior hearing); Coffin Brothers v. Bennett, 277 U.S. 29 (1928) (state superintendent of banks allowed to assess stockholders of insolvent banks without judicial hearing).

42395 U.S. 337 (1969).

43 E.g., Lynch v. Household Fin. Co., 405 U.S. 538 (1972) (attachment of bank accounts); Adams v. Egley, 338 F. Supp. 614 (S.D. Cal. 1972), appeal docketed, No. 72-1484, 9th Cir., Mar., 1972 (repossession under U.G.C. \$\$ 9-503, -504 unconstitutional). Contra, Fampton v. Bank of Cal.,-F. Supp.-(N.D. Cal. 1972), appeal docketed, No. 72-1888, 9th Cir., Mar., 1972; Greene v. First Nat'l Exch. Bank, 348 F. Supp. 672 (W.D. Va. 1972); McCormick v. First Nat'l Bank, 322 F. Supp. 604 (S.D. Fla. 1971). See also, Santiago v. McElroy, 319 F. Supp. 284 (E.D. Pa. 1970) (three-judge court) (levy on tenant's possessions by landlord held unconstitutional); Klim v. Jones, 315 F. Supp. 109 (N.D. Cal. 1970) (seizure by innkeeper held unconstitutional). Contra, Kerrigan v. Boucher, 326 F. Supp. 647 (D. Conn.), aff'd on other grounds, 450 F.2d 487 (2d Gir. 1971) (seizure by boarding house manager held constitutional). See also, Hall v. Garson, 468 F.2d 845 (5th Cir. 1972) (levy on tenant's possessions by landlord held unconstitutional); Desmond v. Hachey, 315 F. Supp. 328 (D. Me. 1970) (three-judge court) (imprisonment of judgment debtor unconstitutional); Randone v. Superior Ct., 5 Cal. 3d 536, 488 P.2d 13, 96 Cal. Rptr. 709 (1971) (invalidating California's prejudgment attachment procedures); Jones Press, Inc. v. Motor Travel Servs., Inc., 286 Minn. 205, 176 N.W.2d 87 (1970) (garnishment of accounts receivable held unconstitutional). 
mons and served it on the garnishee. The debtor, who was served with a summons and a copy of the complaint on the same day as the garnishee, moved for dismissal of the proceedings on the grounds that the garnishment procedure failed to provide her with notice and an opportunity to be heard prior to the seizure of her wages. The Wisconsin courts upheld the statute, but the Supreme Court reversed, holding that "the interim freezing of wages without a chance to be heard violates procedural due process." 44

Speaking for the majority, Justice Douglas distinguished previous prejudgment attachment cases on the ground that none of them dealt with wages. The Court held that notice and an opportunity to be heard must precede the attachment of wages for debt collection because of the "grave injustices made possible by prejudgment garnishment," and because wages are a "specialized type of property presenting distinct problems in our economic system." The Court assumed without discussion that no countervailing state or creditor interests sufficient to justify the procedure could be found. ${ }^{45}$

At first a number of lower courts interpreted Sniadach narrowly, confining it to wage garnishments. ${ }^{46}$ The Supreme Court, however, has applied the principles expressed in Sniadach to a variety of cases, and it has become evident that the decision cannot be confined to its narrow holding. ${ }^{47}$ Of these cases, the Court's decision in Fuentes v. Shevin ${ }^{48}$

44395 U.S. at 340 .

45395 U.S. at $341-42$.

46 E.g., Brunswick Corp. v. J. \& P., Inc., 424 F.2d 100 (10th Cir. 1970); Reeves v. Motor Contract Co., 324 F. Supp. 1011 (N.D. Ga. 1971); Black Watch Farms v. Dick, 323 F. Supp. 100 (Conn. 1971); American Olean Tile Co. v. Zimmerman, 317 F. Supp. 150 (Hawaii 1970); Young v. Ridley, 309 F. Supp. 1308 (D.C. 1970); Termplan, Inc. v. Superior Ct., 105 Ariz. 270, 463 P.2d 68 (1969); Mills v. Bartlett, 265 A.2d 39 (Del. Super. Ct. 1970).

47 In Goldberg v. Kelly, 397 U.S. 254 (1970), the Court held that a public assistance recipient must have "timely and adequate notice detailing the reasons for a proposed termination," as well as "an effective opportunity to defend by confronting any adverse witnesses and by presenting his own arguments and evidence orally." Id. at 267-68. As in Sniadach, the Court stressed the extreme hardship involved in the termination of benefits if the recipient was in fact eligible. Balancing this hardship against the interest of saving the state money, the Court found that there were other adequate means to protect the public fisc. Goldberg indicated that the Court did not intend to limit the applicability of Sniadach to wage garnishment, and a number of subsequent decisions gave further evidence of the Court's committment to the broad principles of due process; cf. Stanley v. Illinois, 405 U.S. 645 (1972); Bell v. Burson, 402 U.S. 535 (1971); Boddie v. Connecticut, 401 U.S. 371 (1971); Wisconsin v. Constantineau, 400 U.S. 433 (1971); Wheeler v. Montgomery, 397 U.S. 280 (1970). Nonetheless, because some of the Court's decisions dealt with "necessities" such as wages and welfare benefits, some courts and commentators viewed Sniadach and Goldberg as radical departures from established due process principles and limited to cases involving the necessities of life. See cases cited note 46 supra; the Supreme Court, 1968 Term, 83 HARv. L. REv. 1, 117-18 (1969).

48407 U.S. 67 (1972). The statutes involved in Fuentes provided no prior, impartial deter- 
is particularly relevant to the question of the constitutionality of power of sale. In Fuentes the Court found unconstitutional state statutes authorizing state officers to seize property on the ex parte application of any person who alleged a right to possession and posted a bond. Writing for a 4-3 majority, ${ }^{49}$ Justice Stewart stressed that, in most circumstances, due process requires notice and an opportunity for a hearing before any state taking of property. ${ }^{50}$ The Court found irrelevant the fact that the consumer goods involved may not have been "necessities." In addition, noting that although the plaintiffs lacked full legal title, they had obtained a right to the possession of the property, the Court held that such possessory interests are constitutionally protected. ${ }^{\mathbf{1}}$

Fuentes left many questions unanswered. The Court said that in some "extraordinary situations," notice may be contemporaneous with the seizure and the hearing may be postponed, ${ }^{52}$ and it refused to articulate a set of minimum safeguards to be observed when a hearing is required. ${ }^{53}$ Most importantly, perhaps, the opinion suggests that it may be possible for a debtor to waive his rights to prior notice and a hearing at the time he enters into the contract..$^{54}$ Despite these qualifications, the Court's decisions in Sniadach and Fuentes establish a general rule that notice and an opportunity for a hearing must be provided before a state may deprive a person of his possessory rights in property. In light of these decisions, security devices such as mechanic's liens,

mination of the actual rights of the parties and are typical of similar statutes effective in forty-eight states and the District of Columbia. See The Stppreme Court, 1971 Term, 86 HARv. L. REv, 1, 86 (1972). The net result of the statutes is that the sheriff is used as a private "debt collection service" for lenders under conditional sales contracts. See generally D. Caplovitz, The Poor Pay More 161-67 (Free Press ed. 1967).

49 Justice White, joined by the Chief Justice and Justice Blackmun, vigorously dissented, noting that normally a debtor has few defenses available to him since he has either paid or not paid. Justice White argued that if a debtor did default, then it is "not only "fair" but essential, that the creditor be allowed to repossess," and refused to conclude "that the likelihood of a mistaken claim of default is sufficiently real or recurring to justify . . ." the Court's holding. Justices Porvell and Rehnquist did not participate in the decision. 407 U.S. at $89,100$.

60407 U.S. at 80.

51407 U.S. at $86-87$.

62 Justice Stewart emphasized that these cases must be truly unusual and suggested three criteria: an important public interest, a need for very prompt action, and strict state control over the use of the procedure. 407 U.S. at 90-92.

53 "The nature and form of such prior hearings, moreover, are legitimately open to many potential variations and are a subject, at this point, for legislation-not adjudication." 407 U.S. at 96-7. This fact could undermine the value of the Fuentes decision to debtors. Cf. Lindsey v. Normet, 405 U.S. 56 (1972); The Supreme Court, 1971 Term, supra note 48 , at $90-91$.

54407 U.S. at 95-96. 
federal tax liens, set-off agreements with bankcards, and self-help procedures under both Articles 2 and 9 of the Uniform Commercial Code may be found unconstitutional. Similarly, it may be argued that the power of sale method of foreclosure violates the standards of due process.

\section{B. Is There Sufficient "State Action" in the Power of Sale?}

In determining whether foreclosure by private sale is consistent with due process, the threshold question is whether it constitutes "state action"; if there is only "passive" state involvement or none at all, power of sale would not be subject to the due process standards of the fourteenth amendment.55 As noted above, power of sale is expressly authorized by contractual agreement. Unlike the garnishment in Sniadach or the seizure of property in Fuentes, it does not involve any direct action or review by state officials. ${ }^{56} \mathrm{It}$ is, therefore, arguable that in the case of power of sale there is no predicate for the application of the fourteenth amendment. ${ }^{57}$ Nonetheless, there are two theories under which state action in power of sale could be found.

The first theory, which argues that state action is present because statutes regulate power of sale, derives support from Reitman v. Mul-

55 The Due Process Clause provides: "nor shall any State deprive any person of life, liberty, or property, without due process of law." U.S. CoNsT. amend. XIV, § 1. The wording makes clear that "state action" is required, and that this clause does not govern purely private conduct. Cf. Lloyd Corp. v. Tanner, 407 U.S. 551, 567 (1972); Moose Lodge No. 107 v. Irvis, 407 U.S. 163 (1972); Shelley v. Kraemer, 334 U.S. 1, 13 (1948); Civil Rights Cases, 109 U.S. 3 (1883).

50 In Sniadach, of course, the finance company could not seriously argue a lack of state action since the deprivation of wages came as a result of a writ of garnishment issued by a state court; in Fuentes, the action by the state included the issuance of the writ of replevin, the service of the writ by the sheriff, and the taking of possession by the sheriff. Direct state action might be found in the power of sale, however, in the rather extensive state and federal lending programs. Whether the government is a direct lender or only a guarantor of a private loan, the government is often directly involved in the liquidation of the security.

67 In 1935, when the California power of sale statute was under attack, the Ninth Circuit affirmed a lower court dismissal for lack of the requisite state action. Davidow v. Lachman Bros. Ins. Co., 76 F.2d 186 (9th Gir. 1935). Since that time, and even after the Sniadach decision, California courts have continued to find inadequate state action to bring the power of sale under the Fourteenth Amendment. See Strutt v. Ontario Sav. \& Loan Ass'n, Il Cal. App. 3d 547, 90 Cal. Rptr. 69 (1970), appeal denied, 11 Cal. App. 3d 551. Another California decision, however, found adequate state action in the mere existence of a statute authorizing self-help. Adams v. Egley, 338 F. Supp. 614 (S.D. Cal. 1972), appeal docketed, No. 72-1484, 9th Cir., Mar., 1972. Contra, Hampton v. Bank of Cal.,-F. Supp.-(N.D. Cal. 1972), appeal docketed, No. 72-1888, 9th Cir., Mar., 1972; Greene v. First Nat'l Exch. Bank, 348 F. Supp. 672 (W.D. Va. 1972); McCormick v. First Nat'l Bank 822 F. Supp. 604 (S.D. Fla. 1971). 
key.58 In Reitman, the plaintiffs brought an action under the Unruh Givil Rights Act claiming that the defendants had refused to rent plaintiffs an apartment because of their race. The defendants relied on Section 26 of article I of the California Constitution (commonly known as Proposition 14), which had been enacted by referendum after the plaintiffs' action had been filed. ${ }^{59}$ The California Supreme Court examined Proposition 14's historical context, as well as its immediate objective and ultimate effect, and found that its sole purpose was to overturn state antidiscrimination statutes, to prohibit the enactment of such laws in the future, and to create a constitutional right to discriminate, thereby making the state "at least a partner" in acts of racial discrimination. ${ }^{60}$ In finding that Proposition 14 violated the fourteenth amendment's equal protection clause, the California court emphasized that the proposition changed preexisting law and did not simply adopt a policy of state neutrality. ${ }^{61}$

A number of factors, however, militate against the application of Reitman's theory of state action to power of sale. Since the primary purpose of the fourteenth amendment was the elimination of racial discrimination, ${ }^{62}$ the Court has been willing to extend the concept of state action to reach carefully disguised attempts by some states to put racially discriminative practices into "private" hands. ${ }^{.3} \mathrm{But}$, of course, power of sale involves no racial discrimination and Proposition 14 did not codify the common law as power of sale statutes do. Finally, and probably most importantly, an extension of Reitman to cover power of sale would subject most private conduct to fourteenth amendment standards. ${ }^{64}$ Since statutes and laws regulate most forms of private

58387 U.S. 369 (1967).

59 Proposition 14 provided, in part, that "[n]either the State nor any subdivision or agency thereof shall deny, limit or abridge, directly or indirectly, the right of any person, who is willing or desires to sell, lease or rent any part or all of his real property, to decline to sell, lease or rent such property to such person or persons as he, in his absolute discretion, chooses." 387 U.S. at 371 , n.2.

60 Mulkey v. Reitman, 64 Cal. 2d 529, 50 Cal. Rptr. 881, 413 P.2d 825 (1966).

61 Id. at $542-3$.

62 Slaughter House Cases, 83 U.S. 36, 71-72 (1873).

63 Accordingly, the Court has found adequate state action in the following areas of private conduct: (1) where state officials have acted in concert with private parties, United States v. Price, 383 U.S. 787 (1966); (2) where the state has.become a "joint participant" in the challenged activity, Burton v. Wilmington Parking Authority, 365 U.S. 715, 725 (1961); (3) where the private individual is performing an essentially governmental function as an agent of the state or with state cooperation, Evans v. Newton, 382 U.S. 296 (1966); Marsh v. Alabama, 326 U.S. 501 (1946); Smith v. Allwright, 321 U.S. 649 (1944); and (4) where the state has required or coerced the challenged action by the private party. Moose Lodge No. 107 v. Irvis, 407 U.S. 163 (1972); Barrows v. Jackson, 346 U.S. 249 (1953); Shelley v. Kraemer, 334 U.S. 1 (1948).

64 For example, virtually all contractual relations woụd be subject to both due process 
activity, any extension of the Reitman reasoning must be done cautiously. ${ }^{\text {es }}$

The second theory is that the state's enforcement of the private power of sale agreement is sufficient to find state action. For example, in Shelley $v$. Kraemer the Supreme Court found sufficient state action in the judicial enforcement of a racially restrictive private covenant. ${ }^{66}$ As Professor Gunther points out, however, the Court has rejected an expansive reading of Shelley and has stressed that state action will not be found when there is no active assistance or cooperation on the part of the state. ${ }^{67}$

In those cases in which the lower courts have found sufficient state action in private creditor remedies, it has been assumed that statutory authorization of the remedy encourages its use and makes the state a partner in the activity. ${ }^{\text {es }}$ Other courts, however, have rejected this reasoning, on the ground that even if the existence of the statute encourages creditors to use the remedy, the encouragement is passive and not sufficient to find state action. ${ }^{69}$ It appears, therefore, that a

and equal protection assaults; and many gifts would also be subject to attack, including testamentary dispositions.

65 See generally B. BITtKer \& K. KAUfMan, Taxes and Givil Rights: "Constitutionalizing" the Internal Revenue Code, 82 YALE L.J. 51 (1972). The Court recently refused to broaden the Reitman concept of state action in Moose Lodge No. $107 \mathrm{v}$. Irvis, 407 U.S. 163 (1972). In Moose Lodge, Justice Rehnquist found that even a pervasive state liquor licensing scheme did not implicate the state directly in the discriminatory practices and policies of the private party in serving liquor under a license, 407 U.S. at 171-78. The Court noted that state action will not be found unless the state has "significantly involved itself" in the challenged practice. 407 U.S. at 173.

66334 U.S. 1 (1948).

67 G. Gunther \& N. Dowling, Constitutional Law 475-81 (8th ed. 1970); cf. Black v. Cutter Laboratories, 351 U.S. 292 (1956), in which Justice Douglas argued in a dissenting opinion that state action was present in the discharge of a member of the Communist Party by a private employer because of a state court decision that authorized the challenged discharge. Cf. The Supreme Court, 1968 Term, supra note 47, at 118. In Lloyd Corp. v. Tanner, 407 U.S. 551 (1972), the Court found insufficient state action to support a claim that a private shopping center's use of uniformed guards to prevent leafleting violated the first amendment even though the guards had been deputized and trained by the state. The state involvement would certainly appear to be greater than that involved in private foreclosure under a contractual power of sale. In Particular Cleaners, Inc. v. Commonwealth Edison Co., 457 F.2d 189 (7th Cir.), cert. denied, 41 U.S.L.W. 3188 (U.S. Oct. 10, 1972), the plaintiffs filed an action challenging the utility's security deposit practices on equal protection grounds, claiming that state regulation constituted sufficient state action. The court rejected this contention. "The [state regulation] in no way directs or orders the collection of any security deposits. It merely serves to limit the power of public utilities to require deposits." Id. at 190. By analogy, regulation of power of sale by state statute would not be sufficient state action.

08 E.g., Adams v. Egley, 338 F. Supp. 614 (S.D. Cal. 1972), appeal docketed, No. 72-1484, 9th Cir., Mar., 1972.

09 E.g., Greene v. First Nat'l Exch. Bank, 348 F. Supp. 672 (W.D, Va, 1972). 
good case can be made for exempting power of sale from due process requirements because of a lack of sufficient state action. Nonetheless, other rationales that may reconcile power of sale with the due process requirements discussed above must be considered.

\section{Is There an "Opportunity to Be Heard" in the Power of Sale?}

Assuming that power of sale is subject to the fourteenth amendment, it is necessary to apply the principles of due process properly. While due process requires that a person be afforded "notice and an opportunity to be heard before he can be deprived of life, liberty, or property," "70 concept of "an opportunity to be heard" is not selfdefining.

Sniadach and Fuentes do not require that a hearing actually be held, but only that the debtor have an opportunity to test the "validity, or at least the probable validity" of the creditor's claim before being forced to give up his possessory interest. ${ }^{71}$ This can be interpreted to mean that the creditor must provide the debtor with notice, plus adequate time before the deprivation occurs, to take action either to cure the default or to contest the "probable validity" of the creditor's claim. ${ }^{22}$ In both Sniadach and Fuentes, notice had been given contemporaneously with the deprivation, and there was no time for the debtor to do anything to prevent his loss. Power of sale, unlike replevin, garnishment, or self-help remedies such as repossession under sections 9-503 and 9-504 of the Uniform Commercial Code, provides a time period between notice and the actual deprivation of property. This time period allows a mortgagor to sue to enjoin the sale, arguably giving him an opportunity for judicial hearing prior to the sale of his property. ${ }^{73}$

In Lindsey v. Normet ${ }^{74}$ the Supreme Court sustained the Oregon Forcible Entry and Wrongful Detainer Statute against due process challenges. Under the statute, the landlord could bring an action for

70 See text and note at note 40 supra.

71 See 407 U.S. at 97, quoting Sniadach v. Family Fin. Corp., 395 U.S. 337, 343 (1969) (Harlan, J., concurring).

72 Cf. Wilson v. Dietz, 456 F.2d 314 (6th Cir.), cert. denied, 408 U.S. 928 (1972).

73 See Roos v. Belcher, 79 Idaho 473, 321 P.2d 210 (1958), in which the Idaho Supreme Court sustained the power of sale on the grounds that after the mortgagor receives notice of the intent to foreclose the "courts are always open to hear and determine the complaint of any interested party deeming himself aggrieved . . . "' Id. at 479, 321 P.2d at 213. See also Great Falls Nat'l Bank v. McCormick, 152 Mont. 319, 448 P.2d 991 (1968). Both cases, however, were decided before Sniadach and Fuentes, and there was no discussion of whether the opportunity to be heard was available at a meaningful time and in a meaningful manner.

74405 U.S. 56 (1972). 
possession whenever a tenant was ten days late with the rent payment; the tenant was forced to defend within four days of the filing of the action and was barred from raising other defenses such as the failure of the landlord to keep the premises properly repaired. Although it was argued that judicial hearing of this sort does not afford a tenant who may be deprived of his possessory interest in the real estate a complete opportunity to be heard, ${ }^{75}$ the Court found that, since " $[t]$ he tenant is not foreclosed from instituting his own action against the landlord and litigating his right to damages or other relief in that action," the limited opportunity to be heard prior to eviction did not violate procedural due process. ${ }^{76}$

Measured against the due process standards of Lindsey, the 30-120 day period between notice of intent to foreclose and the actual sale seems to afford the mortgagor a much better opportunity to obtain a complete judicial hearing prior to sale. Lindsey may, however, be distinguishable from the power of sale case on the ground that the Court was dealing with an extraordinary situation exempted from normal due process requirements. ${ }^{77}$

In addition, forcing a financially distressed mortgagor to bear the burden of obtaining any hearing by commencing litigation may not

75 Justice Douglas argued that "the theoretical opportunity to be heard and interpose a defense" was a promise of "empty words," since the trial is likely to be held in the presence only of the judge, the landlord, and the landlord's lavver. Id. at 85 (Douglas, J., dissenting).

78 Id. at 66. See also Wilson v. Dietz, 456 F.2d 314 (6th Gir.), cert. denied, 408 U.S. 928 (1972), in which the Sixth Circuit reviewed a welfare termination procedure that placed the burden of seeking a hearing on the welfare recipient. Noting that the procedure provided adequate time for a hearing prior to the termination, if the hearing was requested, the court cited the first sentence of Goldberg: "The question for decision is whether a state that terminates public assistance payments to a particular recipient without affording him the opportunity for an evidentiary hearing prior to termination denies the recipient procedural due process." Id. at 315 (emphasis in Wilson opinion). The Wilson court found that "if the Court had meant what appellant contends, the words "the opportunity for' would have been deleted from the material." Id. at 315. Therefore, in the Sixth Circuit, before the payment of AFDC benefits may be suspended there need be only an opportunity for the recipient to request and receive a hearing.

77 See text and note at note 52 supra. It could be argued that in the case of the Oregon statute there was strict state control over the use of the procedure, which is not present in the purely nonjudicial power of sale, that there is greater need for prompt action in the case of a defaulting tenant than in the case of a defaulting mortgagor because of the lack of "equity cushion" available to a landlord, and that the public interest is greater in the case of defaulting tenants than in the case of mortgagor default because of the greater likelihood of unjust financial loss to the complaining party. On the other hand, many of the same factors are present in the power of sale that were present in Lindsey: the potential for waste, the normal lack of "good defense", the "opportunity costs" involved in delay, the potential for abuse; and the potential harms likely to be suffered by the defaulting party who loses his residence. 
provide a "meaningful opportunity to be heard." A mortgagor attempting to obtain an injunction against sale of his property must meet a higher standard of proof than if he were defending himself in judicial foreclosure; he must also take the initiative to commence the suit. ${ }^{78}$ It does not seem implausible to expect that the transaction costs involved in obtaining a hearing under a power of sale may simply convince many mortgagors to forego judicial supervision and "give up and suffer." "r It might be argued, therefore, that interpreting an "opportunity to be heard" to require only that a debtor be notified of the intended deprivation sufficiently in advance to allow him to take judicial action is not in keeping with the broad, underlying reasoning found in Sniadach and its progeny; formal opportunity to be heard that, in reality, fails to protect the debtor's interest may be inadequate under due process standards.

Nonetheless, in light of Lindsey and the Court's statement that " $\mathrm{t}] \mathrm{he}$ nature and form of such prior hearings ... are legitimately open to many potential variations and are a subject, at this point, for legislation -not adjudication,"80 it can be argued that a state may place the burden of obtaining a hearing on the debtor when adequate prior notice is given. If this is the case, then power of sale poses few constitutional problems; on the other hand, if Sniadach and Fuentes are construed broadly, and if Lindsey is limited as an example of an "extraordinary situation," the constitutionality of power of sale would remain in doubt.

\section{Can Due Process Hearing Rights Be Waived in the Mortgage Instrument?}

Assuming that state action is found in power of sale, and that some form of notice and hearing are required before foreclosure, it may be possible for debtors to waive these rights, thereby validating power of sale. The Supreme Court has often recognized that under some circumstances a party may agree to forego the procedural protections granted by the due process clause. In Boddie v. Connecticut, for ex-

78 It might be possible for a mortgagor to force the lender to bring a judicial action by allowing the foreclosure sale to procede but by refusing to leave the premises, thus forcing the mortgagee to bring an eviction proceeding. This alternative is useful only if the mortgagor may raise other defenses in the eviction suit.

79 There are other circumstances, however, in which a debtor may be forced to commence litigation-for example, when the creditor holds property as collateral or has gained control of it after the default. If low- or no-cost legal aid is available, it can be argued that requiring a debtor to commence litigation is not a burden on his constitutional rights.

80 Fuentes v. Shevin, 407 U.S. 67, 96-97 (1972). 
ample, Justice Harlan noted that "the hearing required by due process is subject to waiver, and is not fixed in form." 81

Fuentes seems to indicate that it is possible for a debtor to waive his preseizure hearing rights if the circumstances essentially conform with the criteria for a valid waiver discussed in $D$. H. Overmyer Co. v. Frick ${ }^{82}$ and $S w a r b$ v. Lennox. ${ }^{83}$ Those cases dealt with the constitutionality of confession of judgment clauses, which permit a debtor to agree in advance to allow the creditor to enter judgment against him without any prior notice or hearing. ${ }^{84}$ In Overmyer the Court held valid a confession of judgment clause agreed to by two commercial enterprises with the advice of counsel and through legitimate bargaining. The Court noted that the circumstances surrounding the waiver are relevant to determining its validity-particularly factors such as inequality of bargaining power, lack of consideration for the waiver, or failure to understand its significance. ${ }^{85}$ In $S w a r b$, the Court noted that the factors listed in Overmyer had "possible pertinancy" especially to the validity of consumer waivers. ${ }^{86}$ In Fuentes, the Court also noted the relevance of these factors and stressed both the likelihood that the use of a standard-form, fine-print contract signified a lack of awareness of the waiver's importance and the disparity of bargaining power between small consumers and large sellers. Thus, commercial mortgagors who have roughly equal bargaining power and the services of legal counsel may validly waive their rights to notice and hearing. ${ }^{87}$ On the other hand, a small homeowner ${ }^{88}$ who borrows from a lending institution may not be able to waive his rights.

In residential real estate, form mortgage contracts are generally used and it is doubtful that most consumers would understand the implication of the waiver clause. In addition, because the lending institution is familiar with mortgage practices and is asked by the

81401 U.S. 371, 378-79 (1971); cf. National Equip. Rental Ltd. v. Szukhent, 375 U.S. 311, 315 (1964).

82407 U.S. 174 (1972).

83407 U.S. 191 (1972).

84 D.H. Overmyer Co. v. Frick, 405 U.S. 174, 176 (1972).

85 Id. at $186-88$.

86 Id. at 201. The Court refused a consumer's request to find the Pennsylvania confession of judgment statute unconstitutional on its face.

87 Accordingly, it would appear that, for complete safety, a commercial mortgagor should be asked to sign a waiver of hearing rights in conjunction with the power of sale clause in the mortgage instrument. Cf. Fein, Yes, A Secured Lender May Still Repossess Personal Property in Illinois Without Prior Notice and an Opportunity for a HearingUnder Certain Circumstances, 54 Crr. B. REc. 110 (1972).

88 Under the ULTC, a sharp distinction is drawn between commercial parties and "protected parties" (that is, owner-occupants of residential real estate). 
mortgagor for a loan, it is often argued that the mortgagee is generally in a superior bargaining position. Furthermore, any "consideration" that is given for a waiver of notice and hearing rights would normally be implicit. Many of these problems might be overcome by lending institutions if they were willing to offer mortgages with an optional waiver clause and if they explained the implications of the waiver. In return for signing the waiver, the mortgagee could offer an explicit reduction in costs that would encourage mortgagors to sign the waiver and that would make the question whether the waiver was "knowing and voluntary" more susceptible to proof. ${ }^{89}$

There are, however, several possible weaknesses in such attempts to assure the validity of a homeowner's waiver. First, the necessity of a full explanation to the mortgagor, combined with other administrative expenses, might make the process undesirable to lending institutions. Also, as noted above, uniformity in mortgage instruments may be required for the development of an efficient national mortgage market. Such uniformity necessarily implies a standard "form" mortgage for nationàl lenders, a requirement arguably in conflict with the "bargained for" waiver clause that would be inserted in some mortgages and deleted from others.90

Thus, a waiver of notice or hearing in the mortgage instrument may be valid generally in the case of large, commercial loans that are individually negotiated and in which form mortgage contracts are seldom used. But in the case of most mortgages involving consumers, a waiver provision under existing practices may not validate a power of sale provision. Even if the waiver is valid, the fact that its validity is a matter for judicial determination might require a hearing prior to sale, thereby undermining the value of power of sale foreclosure. In short, under

89 Even if the mortgagee "bargained for" the waiver as an option in the mortgage contract, the question whether the waiver was valid could still be sufficient to give a mortgagor a "colorable claim" that would require litigation and thereby defeat the purpose and advantage of power of sale. For example, the mortgagor who wants to postpone foreclosure could claim that the rights he waived had not been properly explained to him. If the exercise of power of sale is contingent on a valid waiver, a prior hearing may, in such circumstances, be required to settle the factual dispute. Therefore, even when it is possible to obtain a valid waiver, there can be no assurance that a hearing will not be necessary. Cf. The Supreme Court, 1971 Term, supra note 48, at 94-95. A valid waiver may also require sufficient time to consider the full implications of the rights being surrendered. If so, an applicant for a mortgage could not be confronted with the waiver clause for the first time at the closing, and greater costs would be imposed on the lending institution. Cf. Bissette v. Colonial Mortgage Corp., 340 F. Supp. 1191 (D.D.C. 1972) (disclosure of costs at closing held untimely under the Truth in Lending Act for failure to allow home purchaser sufficient time to consider full costs involved).

90 D. Fand, supra note 34 , at 18-20. 
existing legal doctrines, waiver of hearing rights by small consumers may not permit the use of power of sale.

Whether a consumer who signs a form contract with a large lending institution is a victim of disparate bargaining power is open to question. Many contracts are offered on a take-it-or-leave-it basis, with no negotiation over the terms, in order to reduce transactions costs. ${ }^{91}$ Except in the case of a monopoly, however, the existence of form contracts does not imply that a consumer has been coerced into signing the contract. In a competitive industry like banking, the mortgagor who is offered a printed mortgage contract on a take-it-or-leave-it basis does have a real choice: he may refuse to sign the mortgage, confident that another institution will offer him either better terms or a lower cost if at all possible. What is important for the validity of waivers in the present context is not whether there is negotiation in every transaction, but whether competition forces mortgagees to incorporate in their standard contracts terms that maximize the purchaser's benefits from the transaction.92 According to this theory, waivers that are included in form contracts in terms that are readily comprehensible and in a manner that calls them to the mortgagor's attention should be valid if the banking industry is competitive. ${ }^{93}$ Although few courts have explicitly recognized economic arguments of this type, there are indications that economic theory has an impact on judicial thinking. ${ }^{94}$

\section{E. Does the Power of Sale Present an "Extraordinary Situation" That Justifies Postponing the Opportunity for a Hearing?}

If state action is found in foreclosure by power of sale and if a sufficiently meaningful opportunity for the mortgagor to be heard is not provided, the Court must still balance the interest of mortgagors in protective procedural requirements against the costs they impose. Much of the actual balancing in Sniadach and its progeny has been implicit. In Sniadach the concluding rationale for striking down wage garnishment was that it "may as a practical matter drive a wage earning family

91 The two most obvious ways in which form contracts reduce transactions costs are through saving time for both parties to the contract that might otherwise be spent bargaining over terms, and through savings in personnel costs for the party providing the contract. This latter saving is shown by the fact that a company executive would have to approve each individual contract in the case of negotiation, while he must only approve the contract form once, allowing clerks to use the standard form with minimal supervision.

02 R. Posner, Economic ANalysis of THe LAw $\& 4.8$ (1972) (unpublished, available in The University of Chicago Law School Library).

93 Cf. Fein, supra note 87.

94 See, e.g., H \& H Tire Co. v. United States Dep't of Transp., - F.2d -, (7th Cir. 1972) (Stevens, J., concurring). 
to the wall."95 The Court explicitly used the balancing test in Goldberg $v$. Kelly ${ }^{96}$ and found that the interest of the eligible recipient of welfare in the uninterrupted receipt of public assistance, coupled with the state's interest that his payments not be erroneously terminated, outweighed the state's competing concern of preventing an increase in its administrative and fiscal burdens. Lower court decisions after Sniadach have also used the balancing test. In Fuentes, however, the Court refrained from using an explicit balancing test and stated that the due process requirement of a hearing cannot normally be limited by considerations of efficiency. ${ }^{97}$ The apparent incongruity between the Court's recognition of "extraordinary situations" that may legitimately warrant a prehearing seizure and the Court's reluctance to take cost factors into account in the Fuentes factual setting can be reconciled by viewing the costs imposed on the debtor by the replevin statute to be so great that a careful balancing of interests was unnecessary. ${ }^{98}$ In any event, Fuentes' discussion of "extraordinary situations" indicates that the costs of holding a hearing may, in some circumstances, outweigh any harm suffered by those whose property is taken. ${ }^{99}$

On the surface, it might appear that the Court's balancing has been heavily influenced by the poverty status of the individuals involved. But the Court in Fuentes specifically refused to recognize any such limitation, and Sniadach itself, despite the implications of some of its language, did not find wage garnishment without a hearing unconstitutional only when applied to the poor.

The strongest factor in favor of invalidating power of sale is the effect of an unjust deprivation on the mortgagor and his family. This factor was stressed in both Sniadach and Fuentes. It might be argued that when the deprivation involves the home itself, with the costs and inconveniences of a forced move and consequent strains on familial relationships, the harm is sufficiently great to require prior procedural protections. ${ }^{100}$ The costs to individual debtors who are wrongfully deprived of their homes are compounded by the cost to the state in the form of diminished respect for a system of justice that allows unjust

\footnotetext{
95395 U.S. at $341-42$.

96397 U.S. at 264-66.

97407 U.S. at $90-91$ n.22.

98 Cf. Note, Attachment and Garnishment, 68 Mich. L. REv. 986, 997-98 (1970).

99407 U.S. at $90-92$.

100 Foreclosure can damage a person's business reputation, possibly causing loss of job; and foreclosure is virtually certain to have a deleterious effect upon the debtor's credit rating, an effect that might be substantially lessened if all of the facts were presented in a judicial hearing. Cf. Sniadach v. Family Finance Corp., 395 U.S. 337 (1969).
} 
foreclosures. Strong individual and state interests favor preventing these results whenever possible.

Such considerations, however, are of real concern only if the foreclosure is unjust. Similar considerations in Lindsey $v$. Normet were apparently inadequate to invalidate the Oregon statute. ${ }^{101}$ Foreclosures, like evictions, generally involve parties in strained financial circumstances, and the right to a speedy realization on the mortgaged property after default is as essential for a lending institution as eviction is to a landlord. Foreclosure of the security interest when there is an actual and uncured default is not unjust. ${ }^{102}$

A number of factors that favor power of sale have been discussed above. For example, the debtor, as well as the state, has an interest in less expensive foreclosure methods since they are likely to encourage easier access to mortgage funds, lower interest rates, increased construction and ownership of property, and less litigation. The difficulties of applying a balancing test are illustrated by the following hypothetical example. Assume that 0.5 percent of all power of sale mortgage loans are foreclosed and that one-half of these cases involved unjust foreclosures that would be prevented by judicial foreclosure. ${ }^{103}$ The costs of judicial foreclosure, which directly benefits 0.25 percent of all mortgagors, would be borne by the 99.5 percent who do not have their loans foreclosed and by the 0.25 percent who have their loan foreclosed for valid reasons. ${ }^{104}$ Lending institutions, however, have refined credit operations and have developed elaborate systems for ranking the risk of default. ${ }^{105}$ Thus, a debtor with an "A+" credit rating is forced to share the burden of foreclosure costs only for those in his risk category and receives an appropriately low interest charge. The categories with the highest risk of default include relatively low income persons and young persons who have poor or unestablished credit ratings. Those

101 See text and notes at notes 74-77 supra.

102 The Court apparently considers the debtor's knowledge of the possible consequences of a default an important factor in determining the validity of a particular creditor remedy. Cf. Swarb v. Lennox, 405 U.S. 191 (1972); D. H. Overmyer Co. v. Frick, 405 U.S. 174 (1972); see Fuentes v. Shevin, 407 U.S. 67, 100 (1972) (White, J., dissenting). A mortgagor knows, especially after several notices during the default period, that the property will be sold if he does not cure the default.

103 This is a purposely high estimate in order to state the case in the light most favorable to judicial foreclosure. Cf. 5 FED. HOME LOAN BANK BD. J. 45 (June, 1972).

104 Analytically, judicial foreclosure would therefore appear to provide a sort of compulsory insurance for all mortgagors. It is debatable, however, whether due process really requires that those who do not wish to pay the costs for this "foreclosure insurance" must do so anyway.

105 See Commissioner v. Seaboard Fin. Co., 367 F.2d 646, 648-49 (9th Cir. 1966). 
debtors who either do not default on their mortgages or default and are justifiably foreclosed, bear most of the costs of judicial foreclosure. ${ }^{108}$

The question cannot, however, be answered by calculating who bears the costs, since the Court has frequently protected small minority interests at the expense of the majority. ${ }^{107}$ Many of the same balancing arguments could be used in favor of both wage garnishment and replevin, which were also efficient creditor remedies. ${ }^{108}$ On the other hand, because foreclosure in a power of sale state remains costly, most mortgagees, unlike many lenders in the personal finance industry, seldom resort to repossession until other remedies are exhausted. ${ }^{109}$ Unlike the garnishment and replevin remedies, power of sale is explicitly agreed to in advance by both creditor and debtor. Finally, any balancing test must include the fact that, contrary to the situations in Sniadach and Fuentes, ${ }^{110}$ power of sale requires that notice be given to the debtor before any action is taken, allowing the debtor either to take defensive action or to secure replacement property before the deprivation occurs.

The benefits that flow from the use of power of sale and the significant distinctions between power of sale and the other creditor remedies that have been found invalid strongly suggest that the balance lies in favor of sustaining the constitutionality of power or sale.

\section{ConCLUSION}

This comment has suggested that there exists a need for efficient and final nonjudicial foreclosure and has offered several legal rationales that could be used to reconcile the use of power of sale in real estate foreclosure with the due process requirements of prior notice and hearing found in Sniadach and Fuentes. If the courts desire to retain the use of power of sale, there is adequate legal justification for doing so.

Donald L. Schwartz

106 See generally D. Fand, supra note 34; Johnson, supra note 39.

107 See Boddie v. Connecticut, 401 U.S. 371 (1971); Goldberg v. Kelly, 397 U.S. 254 (1970); Miranda v. Arizona, 384 U.S. 436 (1966).

108 At a minimum, Sniadach and Fuentes require a reexamination of the merits of each particular creditor remedy.

109 " $[1]$ t would not seem in the creditor's interest for a default occasioning repossession to occur; as a practical matter it would much better serve his interests if the transaction goes forward and is completed as planned." Fuentes v. Shevin, 407 U.S. 67, 100 (1972) (White, J., dissenting). Cf. D. Fand, supra note 34; Johnson, supra note 39.

110 See also Adams v. Egley, 338 F. Supp. 614 (S.D. Cal. 1972), appeal docketed, No. 72-1484, 9th Cir., Mar., 1972. 